УДК 349.23:331.106.2(477)

DOI https://doi.org/10.32849/2663-5313/2019.9.13

\title{
Галія Чанишева,
}

докт. юрид. наук, професор,

член-кореспондент Національної академї правових наук Украӥни,

декан сочіально-правового факультету

Національного університету «Одеська юридична академія»

\section{ГЕНЕРАЛЬНА УГОДА: ПОНЯТТЯ, ОЗНАКИ ТА ПРАВОВА ПРИРОДА}

У статті визначаються поняття, ознаки та правова природа генеральної угоди як основного правового акта соціального діалогу у сфері праці. Генеральна угода визначається як договірний правовий акт у формі письмової угоди, що визначає основні принципи формування та реалізаиї державної сочіальної та економічної політики, регулює трудові, соціальні, економічні відносини і укладається між сторонами сочіального діалогу на начіональному рівні в межах їх компетениіі.

На підставі аналізу актів чинного законодавства України виокремлено основні ознаки генеральної угоди як джерела трудового права. Зокрема, з'ясовано, що генеральна угода є основним правовим актом сочіального діалогу; у системі актів трудового законодавства разом з іншими колективними угодами займає проміжне місче між иентралізованими нормативно-правовими актами та локальними нормативно-правовими актами; виконує нормативну, регулятивну $і$ захисну функції; укладається в письмовій формі між сторонами соціального діалогу на національному рівні та ін.; зміст генеральної угоди визначається сторонами в межах їх компетениї; строк дії генеральної угоди визначається угодою сторін; є обов'язковою для сторін, які ї уклали; положення генеральної угоди діють безпосередньо $і є$ обов'язковими для всіх суб'єктів, що перебувають у сфері дї сторін, які підписали угоду; предметом колективних угод є широке коло питань формування та реалізаиї державної економічної та соціальної політики, регулювання трудових, сочіальних, економічних відносин та ін.

За своєю правовою природою генеральна угода є договірним правовим актом, що містить норми права та конкретні зобов'язання сторін соціального діалогу на національному рівні у сфері трудових, соиіальних, економічних відносин.

Зазначається про відсутність законодавчого регулювання колективних угод, у тому числі генеральної угоди, у чинному Кодексі законів про працю України та істотні прогалини у проекті Трудового кодексу України. Вносяться конкретні пропозищї щодо врегулювання колективних угод у зазначених актах з урахуванням позитивного законодавчого досвіду зарубіжних країн.

Ключові слова: колективні угоди, генеральна угода, поняття генеральної угоди, ознаки генеральної угоди, правова природа генеральної угоди.

Постановка проблеми. Відповідно до чинного законодавства України генеральна угода $€$ одним із видів колективних угод. Частиною третьою ст. 2 Закону України «Про колективні договори і угоди» [1] передбачається, що генеральна угода укладається на національному рівні на двосторонній або тристоронній основі. Абзацом другим частини п'ятої ст. 8 Закону України «Про соціальний діалог в Україні» [2] встановлюється, що за результатами колективних переговорів укладається на національному рівні генеральна угода.

У законодавстві України не визначаються поняття, ознаки та правова природа генеральної угоди. Необхідність спеціального дослідження зазначених питань зумовлюється потребами розвитку теорії трудового права та вдосконалення законодавства в цій сфері з метою вирішення спірних питань, які виникають у практиці його застосування.
Аналіз останніх досліджень і публікацій $з$ даної теми. Теоретичні та практичні питання щодо поняття, ознак, розробки, укладення та виконання колективних угод, у тому числі генеральної угоди, аналізуються в роботах Н.Б. Болотіної, М.І. Іншина, Н.М. Клименчук, В.Л. Костюка, С.М. Прилипка, Г.І. Чанишевої, О.М. Ярошенка та ін. Утім, науковці по-різному визначають зазначені поняття, не здійснюючи при цьому грунтовного аналізу їх ознак та правової природи.

Метою даної статті є визначення поняття, ознак та правової природи генеральної угоди, а також внесення теоретично обгрунтованих пропозицій щодо вдосконалення чинного законодавства України в цій сфері.

Виклад основного матеріалу дослідження. У чинному законодавстві України 
відсутне визначення поняття як колективної угоди, так і генеральної угоди як одного з її видів. Поняття генеральної угоди визначається в навчальній літературі. Так, на думку В.Л. Костюка, генеральна угода - це колективна угода, яка укладається на національному рівні між уповноваженими представницькими суб'єктами працівників, роботодавців та держави (Кабінету Міністрів України) із соціальних питань [3, с. 141].

Проте в даному визначенні не зазначається про правову природу генеральної угоди, викликає заперечення точка зору вченого щодо сторін та змісту генеральної угоди.

Що стосується правової природи колективних угод, у тому числі генеральної угоди, то в літературі немає єдності щодо їі визначення. Автори Курсу порівняльного трудового права визначають угоду як акт, що укладається між соціальними партнерами на державному, галузевому (міжгалузевому) чи регіональному рівнях, містить правові норми та їх зобов'язання із приводу встановлення умов праці, зайнятості, соціальних гарантій, додаткового пенсійного забезпечення, розвитку соціальної сфери тощо [4, с. 543].

На думку Н.Б. Болотіної, угода - це правовий акт, що укладається між соціальними партнерами і містить їхні зобов'язання щодо встановлення умов праці, зайнятості та соціальні гарантії для працівників держави, галузі, регіону [5, с. 795].

С.М. Прилипко, О.М. Ярошенко, Н.М. Клименчук визначають колективну угоду як акт, який містить загальні принципи регламентації соціально-трудових відносин і пов'язаних із ними економічних відносин і який укладається між повноважними представниками працівників і роботодавців на державному, регіональному та галузевому рівнях в межах їх компетенції [6, с. 26].

В.Л. Костюк розглядає колективні угоди як акти соціального партнерства, які укладаються на національному, галузевому та територіальному рівнях між уповноваженими представниками працівників та роботодавців, як правило, за участю держави та органів місцевого самоврядування із широкого кола соціально-трудових питань [3, с. 141].

Білоруська вчена О.А. Волк відносить угоди, поряд із міжнародними договорами про працю і колективними договорами, до нормативних угод у трудовому праві. На думку вченої, будучи самостійним джерелом права, нормативна угода має ознаки, що характеризують її, з одного боку, як вид договору, а з іншого - як джерело права, що означає наявність у їі змісті норм права [7, с. 129].

У судовій практиці виникло питання щодо визначення правової природи гене- ральної угоди як адміністративного договору, нормативно-правового акта або інших актів

У контексті поставленого питання генеральна угода не є адміністративним договором, незважаючи на те, що Кабінет Міністрів України є суб'єктом однією із сторін цієї угоди (сторони органів виконавчої влади). Кабінет Міністрів України в даному випадку виступає відповідно до частини другої ст. 4 Закону України «Про соціальний діалог в Україні» суб'єктом сторони органів виконавчої влади як сторони соціального діалогу на національному рівні, тобто виконує представницьку функцію (представляє роботодавців державної форми власності) Згідно 3 п. 2 частини першої ст. 20 Закону України «Про Кабінет Міністрів України» № 794-VIII від 27 лютого 2014 року [8] Кабінет Міністрів України виступає стороною соціального діалогу на національному рівні, сприяє його розвитку, відповідно до закону проводить консультації з іншими сторонами соціального діалогу щодо проектів законів, інших нормативно-правових актів із питань формування і реалізації державної соціальної та економічної політики, регулювання трудових, соціальних, економічних відносин.

Заслуговує на підтримку точка зору вчених, які визначають колективну угоду, а відповідно й генеральну угоду, як правовий акт. Водночас генеральну угоду не можна визначити як нормативно-правовий акт у традиційному його розумінні як результат правотворчої діяльності компетентних державних органів. Генеральна угода як правовий акт соціального діалогу є результатом процесу визначення та зближення позицій, досягнення спільних домовленостей та прийняття узгоджених рішень сторонами соціального діалогу. Вона є правовим актом, оскільки, крім зобов'язань сторін, містить і норми права, але, на відміну від інших нормативноправових актів, укладається в договірному порядку, тому може бути визначена як договірний правовий акт.

Що стосується сторін генеральної угоди, то в наведених вище визначеннях не повною мірою враховуються положення частини другої ст. 3 Закону України «Про колективні договори і угоди» [9] про те, що сторонами колективних угод $€$ сторони соціального діалогу, склад яких визначається відповідно до законодавства про соціальний діалог. Отже, сторонами генеральної угоди $\epsilon$ сторони соціального діалогу на національному рівні, якими у частині другій ст. 4 Закону України «Про соціальний діалог в Україні» визнаються: профспілкова сторона, суб'єктами якої є об’єднання професійних спілок, які 
мають статус всеукраїнських; сторона роботодавців, суб'єктами якої є об'єднання організацій роботодавців, які мають статус всеукраїнських; сторона органів виконавчої влади, суб'єктом якої є Кабінет Міністрів України.

Зміст генеральної угоди закріплений у частині першій ст. 8 Закону України «Про колективні договори і угоди». Видається необхідним внести зміни до частини першої ст. 8 Закону України «Про колективні договори і угоди» з урахуванням положень ст. 1 Закону України «Про соціальний діалог в Україні» та викласти її в такій редакції «Угодою на національному рівні визначаються основні принципи формування та реалізації державної соціальної та економічної політики, зокрема щодо: гарантій праці i забезпечення продуктивної зайнятості; мінімальних соціальних гарантій оплати праці і доходів всіх груп і верств населення, які забезпечували б достатній рівень життя; розміру прожиткового мінімуму, мінімальних нормативів; соціального страхування режиму роботи і відпочинку; умов охорони праці і навколишнього природного середовища; задоволення духовних потреб населення; умов зростання фондів оплати праці та встановлення міжгалузевих співвідношень в оплаті праці; забезпечення рівних прав та можливостей жінок і чоловіків; заборони дискримінації».

Водночас формулювання положень змісту генеральної угоди у загальному вигляді не повинне перетворювати цю угоду в «декларацію намірів». Зокрема, необххдно зберегти роль генеральної угоди як основного правового акта соціального діалогу, програми діяльності їі сторін на національному рівні. Як і будь-якій програмі, генеральній угоді природно притаманна деяка декларативність. Інша річ, що вона не повинна носити лише декларативний характер або дублювати положення чинного законодавства. Генеральна угода, як і інші колективні угоди, повинна містити конкретні зобов'язання сторін, які б реально забезпечували права та інтереси працівників і роботодавців у сучасних соціально-економічних умовах.

Предметом генеральної угоди є не тільки питання регулювання трудових та економічних відносин, а й широке коло регулювання соціальних відносин (у сфері охорони здоров'я, соціального обслуговування, житлової політики та ін.). Потрібно відзначити певний вплив генеральної угоди на правотворчий процес, оскільки вона передбачає конкретні зобов'язання Кабінету Міністрів України 3 розроблення і внесення до органу законодавчої влади конкретних законопроектів.
Представники МОП були схильні оцінювати деякі тристоронні угоди, підписані у країнах перехідного періоду, як декларацію добрих намірів із незначними практичними результатами. Наслідки тристоронніх угод оцінювались у світлі функцій, які в минулому виконували механізми централізованого планування, що забезпечували удаване ефективне вирішення багатьох проблем. Такий підхід був підданий критиці. Практика свідчить, що процес тристороннього регулювання трудових відносин в Украіні, інших країнах Центральної та Східної Європи, незважаючи на значні труднощі та недоліки, повільні темпи, став складовою частиною вирішення проблем перехідного періоду, а тристоронні угоди стали елементом механізму регулювання деяких умов праці, особливо заробітної плати.

На законодавчому рівні колективні угоди вперше були передбачені Законом України «Про колективні договори і угоди» від 1 липня 1993 року. До цього діяли тарифні угоди, які укладалися на міжгалузевому, галузевому, територіальному та виробничому рівнях. Тарифна угода визначалася як договір між представниками сторін переговорів із питань оплати праці та соціальних гарантій. В Україні тарифні галузеві угоди укладалися з 1992 року.

Перша Генеральна угода була укладена в 1993 році між Кабінетом Міністрів України і профспілковими об'єднаннями України відповідно до Декрету Кабінету Міністрів України «Про оплату праці» від 31 грудня 1992 року. 4 серпня 1995 року між Кабінетом Міністрів України і дев'ятьма найбільш крупними профспілковими об'єднаннями України було підписано Генеральну угоду на 1995-1996 року, проте не всі наймані працівники були представлені зазначеними об'єднаннями.

Із часом окреслилась тенденція до розширення кола суб'єктів колективних угод та їхнього змісту. Генеральну угоду на $1997-$ 1998 роки підписали 18 жовтня 1997 року Кабінет Міністрів України, Український сою3 промисловців і підприємців та профспілкові об'єднання України. Генеральна угода містила норми, якими встановлювались соціальні гарантії у сферах зайнятості, оплати праці і прибутків, доплат, надбавок, охорони праці, здоров'я, навколишнього природного середовища та ін.

До Генеральної угоди між Кабінетом Міністрів України і Конфедерацією роботодавців України та профспілковими об'єднаннями України на 1999-2000 роки вперше були включені розділи «Сприяння розвитку виробництва, забезпечення продуктивної 
зайнятості», «Забезпечення соціальних прав та гарантій» у сферах рівня життя, житловій, охорони здоров'я та освіти, соціального страхування, задоволення соціально-культурних та духовних потреб населення.

Чинна Генеральна угода про регулювання основних принципів і норм реалізації соціально-економічної політики і трудових відносин в України на 2019-2021 роки [10] була підписана 14 травня 2019 року відповідно до законів України «Про колективні договори і угоди», «Про соціальний діалог в Україні» між всеукраїнськими об'єднаннями організацій роботодавців в особі Спільного представницького органу сторони роботодавців на національному рівні, всеукраїнськими об'єднаннями професійних спілок в особі Спільного представницького органу репрезентативних всеукраїнських об'єднань профспілок на національному рівні та Кабінетом Міністрів України.

Генеральна угода про регулювання основних принципів і норм реалізації соціально-економічної політики і трудових відносин в Україні на 2019-2021 роки набрала чинності $з$ дня їі підписання. Генеральна угода стала основою для укладення галузевих (міжгалузевих), територіальних угод, колективних договорів.

Генеральні угоди як акти соціального діалогу істотно вплинули на розвиток трудового і соціального законодавства в Україні. Вони стали нормативною основою вирішення складних проблем перехідного періоду до ринкової економіки, сприяли інституалізації соціальних партнерів та розвитку взаємодії між ними.

В Україні Генеральна та територіальні угоди як найбільш поширені акти трипартизму виступають у цей час підгрунтям для подальшого розвитку соціального діалогу на тристоронній основі. Як відзначається в Програмі Гідної праці МОП для України на 2016-2019 роки, в умовах активізації організацій громадянського суспільства щодо їхньої участі в суспільному обговоренні питань, які є традиційними темами тристороннього соціального діалогу, загострюється дискусія щодо ефективності моделі соціального діалогу для України. Соціальні партнери, що обстоюють тристоронню модель соціального діалогу, наголошують на необхідності подальшої розбудови їхньої спроможності для участі у соціальному діалозі саме в тристоронньому форматі.

Недоліком чинного законодавства України в частині регулювання колективних угод $€$ те, що у КЗпП України відсутні норми про зазначені угоди (у главі II йдеться тільки про колективний договір). У зв’язку із чим пропонується іменувати главу II «Колективні угоди і договори» і доповнити її нормами про поняття, види, зміст і сторони колективних угод.

Зазначена прогалина повністю не усунута й в проекті Трудового кодексу України [11] Новелою законопроекту є норми ст. 10 «истема нормативно-правових та інших актів, що регулюють трудові відносини» Книги першої «Загальні положення». Відповідно до частини другої зазначеної статті трудові відносини регулюються також генеральною, галузевими (міжгалузевими) угодами, колективним та трудовим договорами. Сторони колективних угод та колективних договорів, трудового договору мають право врегулювати в угоді чи договорі відносини, не врегульовані трудовим законодавством. У Книзі шостій «Колективні трудові відносини» відсутні спеціальні норми про колективні угоди і договори.

Хоча зміст ст. 10 і є недосконалим (у частині другій пропущені територіальні угоди, йдеться про право сторін колективних угод і колективних договорів врегулювати в угоді «відносини, не врегульовані трудовим законодавством», хоча у визначенні поняття соціального діалогу в Законі України «Про соціальний діалог в Україні» (ст. 1) зазначається про регулювання трудових, соціальних, економічних відносин), все ж включення колективних угод і колективних договорів до актів, які регулюють трудові відносини, $€$ правильним і необхідним.

У трудових кодексах багатьох зарубіжних країн відповідні розділи (глави) називаються «Колективні договори і угоди», в яких закріплені норми про поняття, види, зміст i структуру угод, порядок розробки проекту угоди та її укладення, дію угод, їх зміну і доповнення, реєстрацію, контроль за виконанням. Наприклад, у Розділі IV «Загальні правила регулювання колективних трудових відносин» Трудового кодексу Республіки

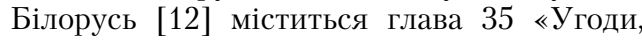
колективні договори».

\section{Висновки}

Таким чином, поняття генеральної угоди доцільно визначити на підставі актів чинного законодавства, виходячи з її правової природи, форми, сторін та змісту. Генеральна угода - це договірний правовий акт у формі письмової угоди, що визначає основні принципи формування та реалізації державної соціальної та економічної політики, регулюе трудові, соціальні, економічні відносини і укладається між сторонами соціального діалогу на національному рівні в межах їх компетенції. 
Видається доцільним змінити назву генеральної угоди та іменувати iї генеральною угодою про основні принципи формування та реалізації державної соціальної та економічної політики. Викликає заперечення використання в назві чинної Генеральної угоди слова «регулювання», в поєднанні в назві з принципами і нормами це видається нелогічним, адже не можна регулювати «принципи» і «норми».

Аналіз чинного законодавства дозволяе виокремити такі ознаки генеральної угоди як джерела трудового права: 1) генеральна угода $є$ основним правовим актом соціального діалогу; 2) у системі актів трудового законодавства разом з іншими колективними угодами займає проміжне місце між централізованими нормативно-правовими актами та локальними нормативно-правовими актами; 3) виконує нормативну, регулятивну і захисну функції; 4) укладається в письмовій формі; 5) укладається на національному рівні соціального діалогу; 6) сторонами генеральної угоди є сторони соціального діалогу на національному рівні; 7) зміст генеральної угоди визначається сторонами в межах їх компетенції; 8) строк дії генеральної угоди визначається угодою сторін; 9) є обов'язковою для сторін, які іiі уклали; 10) положення генеральної угоди діють безпосередньо і є обов'язковими для всіх суб'єктів, що перебувають у сфері дії сторін, які підписали угоду; 11) предметом колективних угод $€$ широке коло питань формування та реалізації державної економічної та соціальної політики, регулювання трудових, соціальних, економічних відносин; 12) умови генеральної угоди, що погіршують порівняно із чинним законодавством становище працівників, є недійсними, і забороняється включати їх до угоди; 12) процедура укладення генеральної угоди визначається законом; 13) генеральна угода діє і набирає чинності у встановленому законом порядку; 14) $є$ правовою основою для укладення галузевих (міжгалузевих), територіальних угод, колективних і трудових договорів.

За своєю правовою природою генеральна угода є договірним правовим актом, що містить норми права та конкретні зобов'язання сторін соціального діалогу на національному рівні у сфері трудових, соціальних, економічних відносин.

\section{Список використаних джерел:}

1. Про колективні договори і угоди: Закон України від 01.07.1993 № 3356-XII. Відомості Верховної Ради України. 1993. № 36. Ст. 361.

2. Про соціальний діалог в Україні : Закон України від 23.12.2010 № 2862-VI. Відомості Верховної Ради України. 2011. № 28. Ст. 255.

3. Костюк В.Л. Трудове право України : підручник / за заг. ред. М.І. Іншина, В.Л. Костюка. Київ : Юрінком Інтер, 2017. 600 с.

4. Курс порівняльного трудового права : підручник у 2 томах / Іншин М.I., Мацюк A.P., Соцький А.М., Щербина В.I. / За ред. акад. А.Р. Мацюка. 2-ге вид., змін. і доп. Харків : Діса плюс, 2015. Т.1. 1056 с.

5. Болотіна Н.Б. Трудове право України : підручник / Н.Б. Болотіна. 5-те вид., переробл. і доп. Київ : Знання, 2008. 860 с

6. Прилипко С.М., Ярошенко О.М., Клименчук Н.М. Колективні угоди як результат соціального партнерства (сучасний стан і перспективи розвитку). Харків : Вид-во «ФІНН», 2011. 256 с.

7. Волк Е.А. Нормативные соглашения в трудовом праве : монография. Минск : Амалфея, 2013. $292 \mathrm{c}$

8. Про Кабінет Міністрів України : Закон України від 27.02.2014 № 794-VIII. Відомості Верховної Ради України. 2014. № 13. Ст. 222.

9. Про колективні договори і угоди: Закон України від 01.07.1993 № 3356-XII. Відомості Верховної Ради Украӥни. 1993. № 36. Ст. 361.

10. Генеральна угода про регулювання основних принципів і норм реалізації соціально-економічної політики і трудових відносин в України на 2019-2021 роки від 14 травня 2019 року. URL: https://zakon.rada.gov.ua/laws/ show/n0001120-19.

11. Проект Трудового кодексу України № 1658 від 27.12.2014 р., текст законопроекту до другого читання від 24.07.2017 р., включено до порядку денного 2149-VIII від 03.10.2017. URL: http://w1.c1.rada.gov.ua/pls/zweb2/webproc4 1 ?pf3511 $=53221$.

12. Трудовой кодекс Республики Беларусь от 26 июля 1999 года. Национальный реестр правовых актов Республики Беларусь. 1999. № $80.2 / 70$.

The article defines the concepts, features and legal nature of the general agreement as the main legal act of social dialogue in the field of labour. The General Agreement is defined as a contractual legal act in the form of a written agreement that defines the basic principles of formation and implementation of state social and economic policy, regulates labor, social, economic relations and is concluded between the parties of social dialogue at the national level within their competence.

On the basis of the analysis of acts of the current legislation of Ukraine, the main features of the general agreement as a source of labor law are singled out. In particular, it has been found that a general agreement is the main legal act of social dialogue; in the system of labor legislation acts, together with other collective agreements, it occupies an intermediate place between centralized normative-legal acts and local normative-legal acts; performs normative, regulatory and protective functions; is concluded in writing between the 
parties of social dialogue at the national level, etc.; the content of the general agreement is determined by the parties within their competence; the term of the general agreement is determined by the agreement of the parties; it is binding for the parties who have entered into it; the provisions of the general agreement are directly applicable and binding on all the subjects who are within the sphere of acitvity of parties to the agreement; the subject matter of collective agreements is a wide range of issues of formation and implementation of state economic and social policy, regulation of labor, social, economic relations, etc.

By its legal nature a general agreement is a contractual legal act that contains legal norms and specific obligations of the parties to the social dialogue at the national level in the field of labor, social and economic relations.

It is noted that there is no legislative regulation of collective agreements, including the general agreement, in the current Code of Laws on Labour of Ukraine and there are significant gaps in the draft Labor Code of Ukraine. Specific proposals are made on the regulation of collective agreements in these acts, taking into account the positive legislative experience of foreign countries.

Key words: collective agreements, general agreement, definition of the general agreement, features of the general agreement, legal nature of the general agreement. 